\title{
Mechanical behavior and durability of mortars with quartzite and Portland cement after sulfate attack
}

\section{Comportamento mecânico e durabilidade de argamassas com quartzito e cimento Portland após ataque com sulfato}

\author{
Sâmea Valensca Alves Barros ${ }^{1}$, Gelmires de Araújo Neves ${ }^{2}$, \\ Romualdo Rodrigues Menezes ${ }^{2}$, Gerbeson Carlos Batista Dantas ${ }^{1}$, \\ Patrícia Mendonça Pimentel $^{1}$
}

\footnotetext{
${ }^{1}$ Universidade Federal Rural do Semi-Árido, Angicos, RN, Brasil.

${ }^{2}$ Universidade Federal de Campina Grande, Campina Grande, PB, Brasil.

e-mail: sameavalensca@ufersa.edu.br,gerbeson_dantas@hotmail.com, pimentelmp@ufersa.edu.br, gelmires.neves@ufcg.ed.br, romualdomenezes@gmail.com
}

\begin{abstract}
The residues of ornamental rocks, especially quartzite, cause great environmental impact. More impulse has been given to research on the recycling of these residues over the last years, particularly for use as aggregates in concrete and mortar. Nevertheless, the studies conducted so far do not mention the behavior of the mortar blended with aggregates coming from residues of ornamental rocks when under chemical attacks in sulfaterich environment. Thus, in the present study it was sought to add quartzite residues to the mortar, verifying its mechanical behavior and its durability when attacked by sodium sulfate $\left(\mathrm{Na}_{2} \mathrm{SO}_{4}\right)$. The durability of the mortar blended with quartzite residues under sulfate attack was evaluated by the dimensional variation of the test specimens when immersed in sodium sulfate solution, according to the methodology of the NBR 13583 standard. Were used the following complementary techniques: simple compressive strength, X-ray diffraction and thermogravimetric and differential analysis. From the tests, it was verified that the mortars, after attack of sodium sulfate, presented dimensional expansions superior to $0.06 \%$, as well as increased mechanical strength. Therefore, although it was found that the specimens incorporated with quartzite residues were attacked by sulfate, it was observed that it was not able to form sufficient secondary ettringite to mechanically damage the specimens submitted to the sodium sulfate attack.
\end{abstract}

Keywords: Alternative materials, quartzite residue, sulfates, durability.

\section{RESUMO}

Os resíduos de rochas ornamentais, especialmente quartzito, causam grande impacto ambiental. Mais impulso tem sido dado à pesquisa sobre a reciclagem desses resíduos nos últimos anos, particularmente para uso como agregados em concreto e argamassa. No entanto, os estudos realizados até o momento não mencionam o comportamento da argamassa misturada com agregados provenientes de resíduos de rochas ornamentais quando submetidos a ataques químicos em ambientes ricos em sulfato. Assim, no presente trabalho buscou-se adicionar resíduos de quartzito à argamassa, verificando seu comportamento mecânico e sua durabilidade quando atacado por sulfato de sódio $\left(\mathrm{Na}_{2} \mathrm{SO}_{4}\right)$. A durabilidade da argamassa mesclada com resíduos de quartzito sob ataque de sulfato foi avaliada pela variação dimensional dos corpos de prova quando imersos em solução de sulfato de sódio, de acordo com a metodologia da norma NBR 13583. Utilizaram-se as seguintes técnicas complementares: resistência à compressão simples, difração de raios X e análise termogravimétrica e diferencial. A partir dos ensaios verificou-se que as argamassas, após ataque de sulfato de sódio, apresentaram expansões dimensionais superiores a $0,06 \%$, bem como aumento da resistência mecânica. Portanto, embora tenha sido constatado que os corpos de prova incorporados com resíduos de quartzito tenham sofrido ataques por sulfato, observou-se que não foi capaz de formar etringita secundária suficiente para deteriorar mecanicamente os corpos de prova submetidos ao ataque de sulfato de sódio.

Palavras-chave: Materiais alternativos, resíduo de quartzito, sulfatos, durabilidade. 


\section{INTRODUCTION}

Quartzite have great industrial interest due to its application as ornamental rocks. Quartzite are rocks classified according to their geological origin as metamorphic rocks, whose mineralogical composition is constituted mainly by quartz minerals, also presenting feldspar (orthoclase or plagioclase), muscovite and biotite, depending on the type of quartzite present in the region [1].

Quartzite mining and beneficiation companies have as main activities the extraction, cutting and sawing for production of ornamental rocks, which are used in coatings, countertops, lavatories, floors and in construction. During the processing and beneficiation of quartzite blocks, millions of tons of residues are created throughout the world every year [1-3]. These residues end up being improperly discarded, usually causing negative impacts to the environment. Their powder is also responsible for severe public health problems [4-5]. These residues were classified into two types: the first one is quartzite powder, resulting from the abrasion between the saw blade and the rock plates. The second type is the quartzite chunks (pieces of rocks resulting from the cutting of quartzite plates in commercial dimensions), which originates the quartzite sand, after going through the processes of crushing, grinding and sieving.

Both developed and emerging countries have invested in research on the use of these residues as alternative feedstock, aiming at the minimization of environmental impacts and generation of economic and social value. Bacarji et al. [6], Gameiro et al. [7], Ercikdi et al. [8], Tenniche et al. [9] state that the proper management of the residues of ornamental rocks can lead to the diversification of their use as alternative feedstock in construction, specifically as aggregates for concrete and mortar.

Studies on the use of quartzite residues in plastering Portland mortar are presently in preliminary stages. However, must stress that an important and necessary factor that will allow such mortar mixtures to be used in aggressive environments is the proof of their durability under sulfate attack, since Portland mortar is expected to resist to the action of the aggressive agents present in their environment [10]. Sulfate attacks occur frequently, compromising the long-term durability of Portland mortar, leading it to expansions, fissures and deterioration [11].

The reason for this is that sulfate ions $\left(\mathrm{SO}_{4}{ }^{2-}\right)$ react with the tricalcium aluminate $\left(\mathrm{Al}_{2} \mathrm{O}_{3} 3 \mathrm{CaO}\right)$ of the cement or with the alumina of the aggregate, forming ettringite $\left(3 \mathrm{CaO} \cdot \mathrm{Al}_{2} \mathrm{O}_{3} \cdot 3 \mathrm{CaSO}_{4} \cdot 32 \mathrm{H}_{2} \mathrm{O}\right)$ [12-13]. The ettringite that is an expansive element capable of causing gradual loss of compressive strength and integrity to cementitious composites, leading it to a disaggregation process [14-16].

Since the literature does not provide reports on the durability of Portland mortar blended with quartzite residues in sulfated environment, the present work had the purpose of studying the mechanical behavior and the durability of Portland mortar blended with quartzite residues after sodium sulfate attack, according to NBR 13583 [17].

\section{MATERIALS AND METHOD}

\subsection{Materials}

The binding elements used in this work were: Portland Cement CP V ARI MAX (Nacional, Cimento Portland Sociedade Brasileira) for not containing pozzolane in its chemical composition (Table 1), according to the NBR 16697 [18] standard, being a suitable cement type for this investigation since there is no influence of the addition of minerals, except for the carbonaceous material content allowed by the standard; hydrated calcitic lime CH-I coming from Carbomil Industries, located in Limoeiro do Norte - CE, for presenting 87\% of calcium hydroxide $\left(\mathrm{Ca}(\mathrm{OH})_{2}\right), 11 \%$ of calcite $\left(\mathrm{CaCO}_{3}\right)$ and $2 \%$ of free water. The aggregate used came from the quartzite residues produced by the company Tecquímica do Brasil, located in Várzea - PB. Must stress that the quartzite residues were used as aggregates in total replacement to the natural aggregate, just varying the percentage of quartzite according to the experimental design by means of the mixture delineation technique executed by Barros et al. [1], resulting in better mechanical strength for application in construction.

The quartzite residues were labeled: QP, quartzite powder, resulting from the sawing of quartzite plates; and QS, quartzite sand, resulting from the crushing, grinding and classification in ABNT sieve $4(4.8 \mathrm{~mm})$ of quartzite chunks (non-commercial chunks of quartzite plates that were cut into commercial dimensions). Barros et al [1] state that the larger amount of alumina, iron, potassium and smaller amount of silica in the quartzite sand is related to the larger amount of mica present in this residue, whereas the XRD of this residue revealed a larger amount of mica, a material containing iron, potassium and aluminum in its constitution, and also kaolinite, a mineral of clay that contains alumina in its structure. The levels of $\mathrm{Mg}$ and $\mathrm{Ca}$ in the residues are similar, with the difference between the values in the error interval of the experiment. The 
reagent used was commercial anhydrous sodium sulfate $\left(\mathrm{Na}_{2} \mathrm{SO}_{4} \cdot 10 \mathrm{H}_{2} \mathrm{O}\right)$ with molecular weight 142.04 g/mol, reagent produced by Labsynth Produtos para Laboratório Ltda, a company with ISO 9001 certification.

In a previous work, Barros et al. [1] determined the granulometric distribution of these residues and classified the QS as sand of average granulometry. Therefore, according to the NBR 7211 [19], it can be used as mortar aggregate. The QP, in turn, was classified and used as filler material. The Table 2 features physical properties of the QS and QP.

Table 1: Chemical composition of cement, QS and QP.

\begin{tabular}{c|c|c|c}
\hline MATERIAL & CEMENT (\%) & QS (\%) & QP (\%) \\
\hline $\mathrm{CaO}$ & 61.05 & 1.2 & 0.83 \\
\hline $\mathrm{SiO}_{2}$ & 19.14 & 67.5 & 78.29 \\
\hline $\mathrm{MgO}$ & 1.33 & 1.62 & 0.93 \\
\hline $\mathrm{Al}_{2} \mathrm{O}_{3}$ & 5.33 & 17.28 & 11.91 \\
\hline $\mathrm{Fe}_{2} \mathrm{O}_{3}$ & 4.1 & 2.2 & 1.22 \\
\hline $\mathrm{SO}_{3}$ & 4.8 & 0.36 & 0.28 \\
\hline $\mathrm{K}_{2} \mathrm{O}$ & 1.05 & 7.22 & 4.83 \\
\hline $\mathrm{TiO}_{2}$ & 0.5 & - & - \\
\hline $\mathrm{Na}_{2} \mathrm{O}^{\mathrm{a}}$ & 0.69 & - & 0.1 \\
\hline Other oxides & - & 0.1 & 1.61 \\
\hline $\mathrm{C}_{3} \mathrm{~A}$ & 7.18 & Not applicable & Not applicable \\
\hline $\mathrm{PF}^{\mathrm{b}}$ & 2.01 & 2.52 & \\
\hline
\end{tabular}

${ }^{\mathrm{a}} \mathrm{Na}_{2} \mathrm{O}_{\text {eq }}$ : Alkaline equivalent; ${ }^{\mathrm{b}} \mathrm{LI}$ : Loss on Ignition; $\% \mathrm{C}_{3} \mathrm{~A}=2.650\left(\% \mathrm{Al}_{2} \mathrm{O}_{3}\right)-1.692\left(\% \mathrm{Fe}_{2} \mathrm{O}_{3}\right)$

Table 2: Physical properties of the quartzite sand (QS) and of the quartzite powder (QP)

\begin{tabular}{|c|c|c|c|}
\hline & TEST & QS & QP \\
\hline \multicolumn{2}{|c|}{ Unitary or apparent mass $\left(\mathrm{g} / \mathrm{cm}^{3}\right)$} & 1.33 & 1.79 \\
\hline \multicolumn{2}{|c|}{ Powdery material content (\%) } & 1.06 & 100 \\
\hline \multirow{2}{*}{ Granulometry } & Maximum diameter (mm) & 2.4 & Not applicable \\
\hline & Thickness modulus (\%) & 2.9 & Not applicable \\
\hline
\end{tabular}

\subsection{Method}

The durability of the mortar samples blended with quartzite residues under sulfate attack was evaluated by their dimensional variation when immersed in sodium sulfate solution, according to the methodology suggested by the NBR 13583 [17], and with help of the following techniques: simple compressive strength, Xray diffraction, thermogravimetric and differential analysis. The determination of the proportions in mass of the mortar samples blended with QS and QP residues for execution of this study was defined by Barros et al. [1] as follows: 1:3 (cement: 100\% QS and 0\% QP); 1:3 (cement: 85\% QS and 15\% QP); 1:1:6 (cement: lime: $100 \%$ QS and 0\% QP) and 1:1:6 (cement: lime: 85\% QS and 15\% QP). The amount of water for each formulation defined in the mixture delineation was determined by the flow table test, in compliance with the NBR 13276 [20], in order to guarantee the proper workability to the mortar, being adopted the standard spreading of $260 \pm 10 \mathrm{~mm}$. The consistency mixtures can be seen in Table 3 . 
Table 3: Consistency of prepared mortars

\begin{tabular}{c|c|c|c}
\hline MIXTURE & $\begin{array}{c}\text { CONSISTENCY } \\
\text { AVERAGE VALUE }\end{array}$ & $\begin{array}{c}\text { WATER } \\
\text { (ML) }\end{array}$ & A/C \\
\hline $1: 1: 6(0 \%$ QP; $100 \%$ QS) & $266.75 \pm 2.36$ & 520 & 0,74 \\
\hline $1: 1: 6(15 \%$ QP; $85 \%$ QS $)$ & $251 \pm 2.94$ & 490 & 0,71 \\
\hline $1: 3(0 \%$ QP; $100 \%$ QS $)$ & $257 \pm 2.94$ & 460 & 0,34 \\
\hline $1: 3(15 \%$ QP; $85 \%$ QS $)$ & $255.75 \pm 3.30$ & 450 & 0,34 \\
\hline
\end{tabular}

After the definition of the proportions, the mortars were molded prismatic test specimens with dimensions $25 \mathrm{~mm}$ X $25 \mathrm{~mm}$ X $285 \mathrm{~mm}$ for each proportion, which were subjected to a curing period of 28 days in humid chamber with $100 \%$ of relative humidity. The curing time of 28 days allows a raise in the mortar strength with respect to the attack by sulfate ions due to the reduction of $\mathrm{Ca}(\mathrm{OH})_{2}$. After the curing period, three test specimens were immersed in distilled water and three in $\mathrm{Na}_{2} \mathrm{SO}_{4}$ solution during 2 days. The resulting expansion of the sample, in percentage, was determined after 7, 14, 28 and 42 days of immersion, in ambient termperature.

In order to determine the simple compressive strength (SCS), molded cylindrical test specimens with dimensions 50mm X 100mm in the proportions of 1:3 (cement: 100\% QS and 0\% QP); 1:3 (cement: 85\% QS and 15\% QP); 1:1:6 (cement: lime: 100\% QS and 0\% QP) and 1:1:6 (cement: lime: 85\% QS and 15\% QP), cured for 28 days in humid chamber with $100 \%$ of relative humidity. After the curing period, eight test specimens of each proportion were immersed in water and eight of each proportion in sodium sulfate solution for 42 days, and then had their simple compressive strength (SCS) determined according to the ASTM C 780 [21]. The SCS tests were executed in a SHIMADZU AG-IS 100KN universal machine with loading speed of $0.25 \pm 0.05 \mathrm{MPa} / \mathrm{s}$. The test specimens ruptured after sodium sulfate attack were crushed and sieved in ABNT sieve $200(0.074 \mathrm{~mm})$ for chemical and mineralogical characterization, with help of the following techniques: X-ray diffraction (XRD) (Shimadzu XRD 6000 device) and thermogravimetric analysis (TG/DTG) (BP Engenharia Indústria e Comércio's RB-3000 thermal analysis device, with heating speed of from $12.5^{\circ} \mathrm{C} / \mathrm{min}$ to $1000^{\circ} \mathrm{C} / \mathrm{min}$. The standard used in the DTA was aluminum oxide $\left(\mathrm{Al}_{2} \mathrm{O}_{3}\right)$ calcined in air.

Since the NBR 13583 [17] does not specify a limit for the expansion after 42 days of immersion in sodium sulfate solution to classify mortar as resistant to sulfate attack, adopted the limit of $0.06 \%$ established by the ASTM C 452 [22], since it is a methodology for evaluation of Portland cement without mineral additions, such as the one used in this research and a quick test as in the methodology proposed by the NBR 13583 [17].

\section{RESULTS AND DISCUSSION}

Figures 1a and 1b illustrate the expansion curves of the mortar samples blended with QS and QP residues when immersed in sodium sulfate solution over of the 42 days of immersion. The values obtained for the expansions of the Portland mortar samples blended with QS and QP residues at 42 days of exposure to the sodium sulfate attack were: $0.07 \%$ for the proportion 1:3(0\% QP and 100\% QS), $0.07 \%$ for the proportion $1: 3(15 \%$ QP and $85 \%$ QS), $0.07 \%$ for the proportion 1:1:6 (0\% QP and 100\% QS) and $0.06 \%$ for the proportion 1:1:6 (15\% QP and 85\% QS). These values showed that the mortar samples are not resistant to the attack by sodium sulfate when the evaluation method is the dimensional variation of mortar bars immersed in a sodium sulfate solution obtained values were higher than $0.06 \%$ established by the ASTM C 452 standard [22]. 

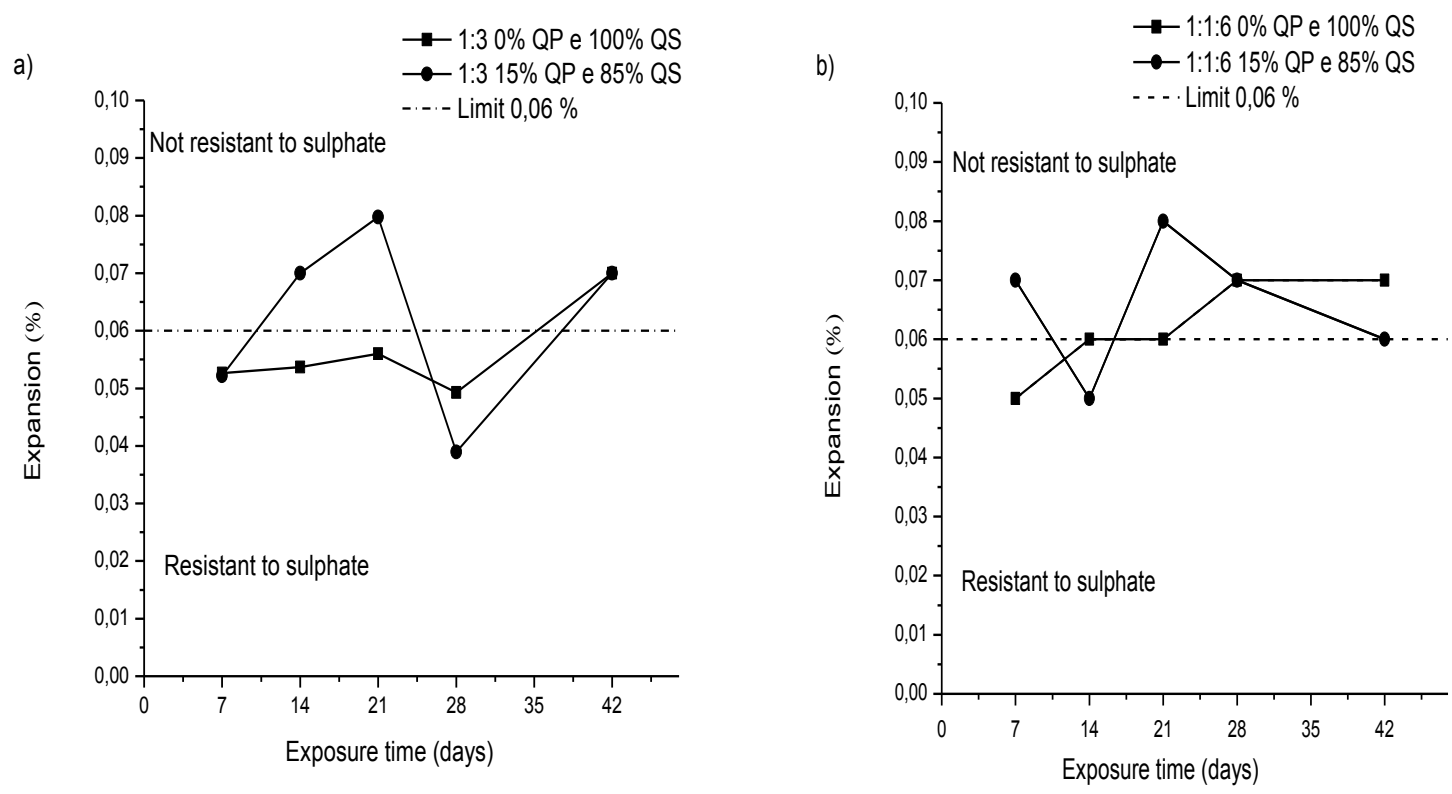

Figure 1: a) Dimensional expansions for the proportion 1:3 and b) Dimensional expansions for the proportion 1:1:6.

The results of the simple compressive strength of the test specimens blended with quartzite residues after immersion in distilled water and in sodium sulfate solution for 42 days are presented in the table 4.

Table 4: Simple compressive strength of the test specimens mixed with QS and QP residues after immersion in distilled water and in sodium sulfate solution

\begin{tabular}{c|c|c|c|c}
\hline PROPORTION & $\begin{array}{c}\text { SCS(MPA) } \\
\text { DISTILLED WATER }\end{array}$ & $\begin{array}{c}\text { COEFFICIENT } \\
\text { OF VARIATION } \\
(\%)\end{array}$ & $\begin{array}{c}\text { SCS (MPA) } \\
\text { SULFATE }\end{array}$ & $\begin{array}{c}\text { COEFFICIENT } \\
\text { OF VARIATION } \\
(\%)\end{array}$ \\
\hline $1: 3-0 \%$ QP and $100 \% \mathrm{QS}$ & $12.97 \pm 0.58$ & 4.47 & $13.40 \pm 0.70$ & 5.22 \\
\hline $1: 3-15 \%$ QP and $85 \% \mathrm{QS}$ & $12.15 \pm 0.94$ & 7.74 & $12.61 \pm 0.31$ & 2.46 \\
\hline $1: 1: 6-0 \%$ QP and $100 \% \mathrm{QS}$ & $2.00 \pm 0.20$ & 10 & $3.33 \pm 0.49$ & 14.71 \\
\hline $1: 1: 6-15 \%$ QP and $85 \% \mathrm{QS}$ & $4.24 \pm 0.64$ & 15.09 & $4.81 \pm 0.42$ & 8.73 \\
\hline
\end{tabular}

The results presented in Table 4 show that there was no loss of the SCS when compare the values obtained after immersion in water and sodium sulfate solution for 28 days for the mortar samples. Therefore, according to the mechanical behavior presented, verified that there was no deterioration of the test specimens, despite they presented characteristic expansions of mortar not resistant to the sulfate attack. Probably, the disaggregation did not occur because the cement presents $\mathrm{C}_{3} \mathrm{~A}$ content below $8 \%$, which indicates, according to the NBR 16697 [18], that the cement is resistant to the sulfate attack. The expansions occurred, possibly, due to the reaction between the alumina present in the aggregates and the sulfate ions, forming ettringite. According to Merida et al. [10], when this reaction happens, can state that the aggregates are reactive to the sulfate ions. Therefore, the test specimens need a longer exposure to sulfate ions in order to present the deterioration and have their mechanical behavior affected, since cement presents a certain degree of resistance against the sulfate attack.

Was verified (Table 4) that the SCS values of the Portland mortar blended with residues of QS and QP immersed in aggressive sulfate solution presented mechanical behavior superior to that recommended by the NBR 13281 [23] which is of at least $2 \mathrm{MPa}$ for use in plastering mortar.

Figures $2 \mathrm{a}$ and $2 \mathrm{~b}$ illustrate the XRD of the mortar proportions 1:3 and 1:6 after immersion in sodium sulfate for 42 days. 

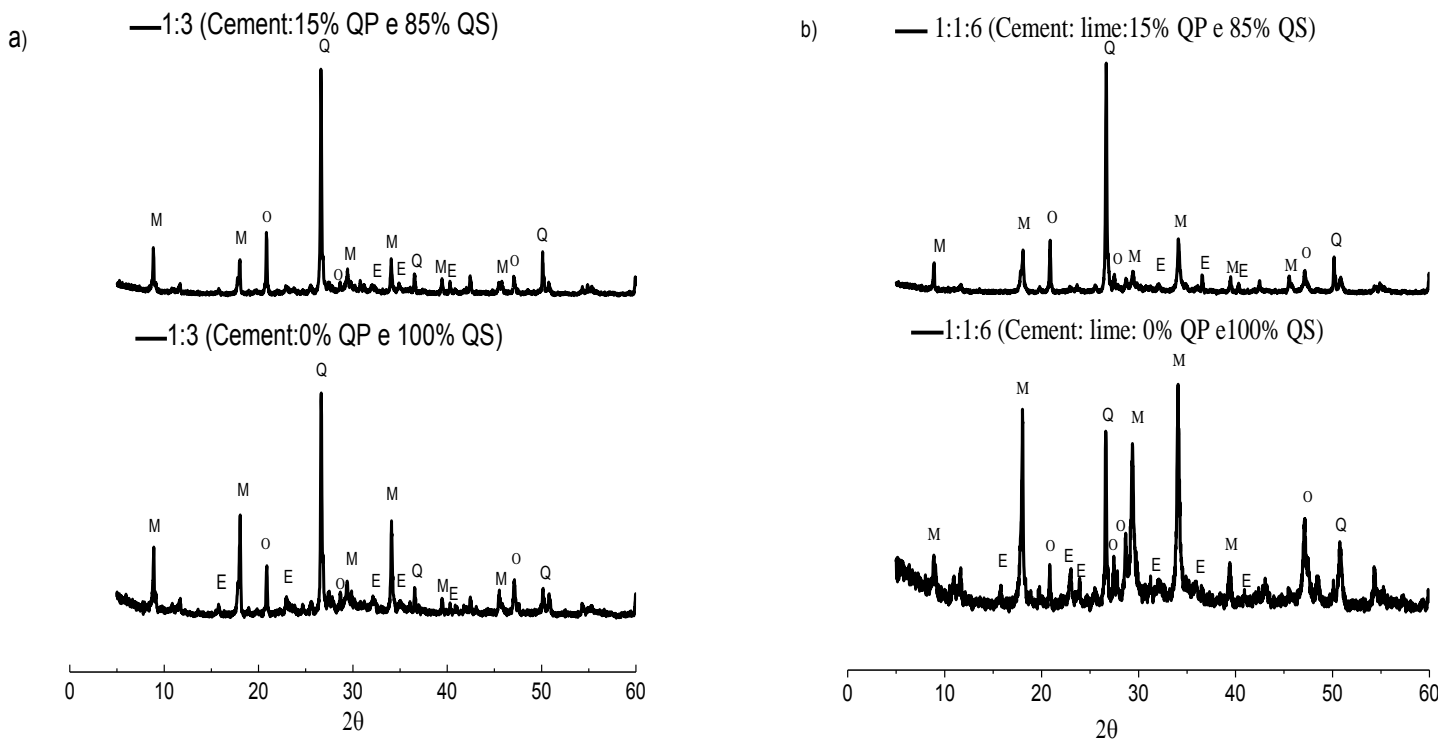

Figure 2: XRD of the mortar after immersion in sodium sulfate a) proportion 1:3 and b) proportion 1:1:6. Where: $\mathrm{E}=$ Ettringite; $\mathrm{M}=\mathrm{Mica} ; \mathrm{O}=$ Orthoclase and $\mathrm{Q}=\mathrm{Quartz}$

Was verified the following phases in the diffractograms file standard Joint Committee on Powder Diffraction (JCPDS): ettringite $\left(3 \mathrm{CaO} . \mathrm{Al}_{2} \mathrm{O}_{3} \cdot 3 \mathrm{CaSO}_{4} \cdot 32 \mathrm{H}_{2} \mathrm{O}\right.$, JCPDS file: 720646$)$; quartz $\left(\mathrm{SiO}_{2}\right.$, JCPDS file: 46-1045); orthoclase ( $\mathrm{KSi}_{3} \mathrm{AlO}_{3}$, JCPDS file:84-0710) and mica $\left(\mathrm{KMg}_{3}\left(\mathrm{Si}_{3} \mathrm{Al}\right) \mathrm{O} 10(\mathrm{OH})_{2}, \mathrm{JCPDS}\right.$ file:831808). Was observed that ettringite was formed in a small amount. According to Brown [24], if the Portland mortar samples present the formation of ettringite but no fissures occur, this is because the amount formed did not exceed a threshold capable of generating tensions in the solid neighbors. With respect to the mortar samples blended with QP, noticed that they were more compact and had fewer pores due to the filler effect of the quartzite powder, and this is probably the reason for the reduced amount of ettringite formed.

Figures 3a and 3b illustrate the TG and DTG curves of the mortar blended with the QS and QP residues after immersion in sodium sulfate solution for 42 days.

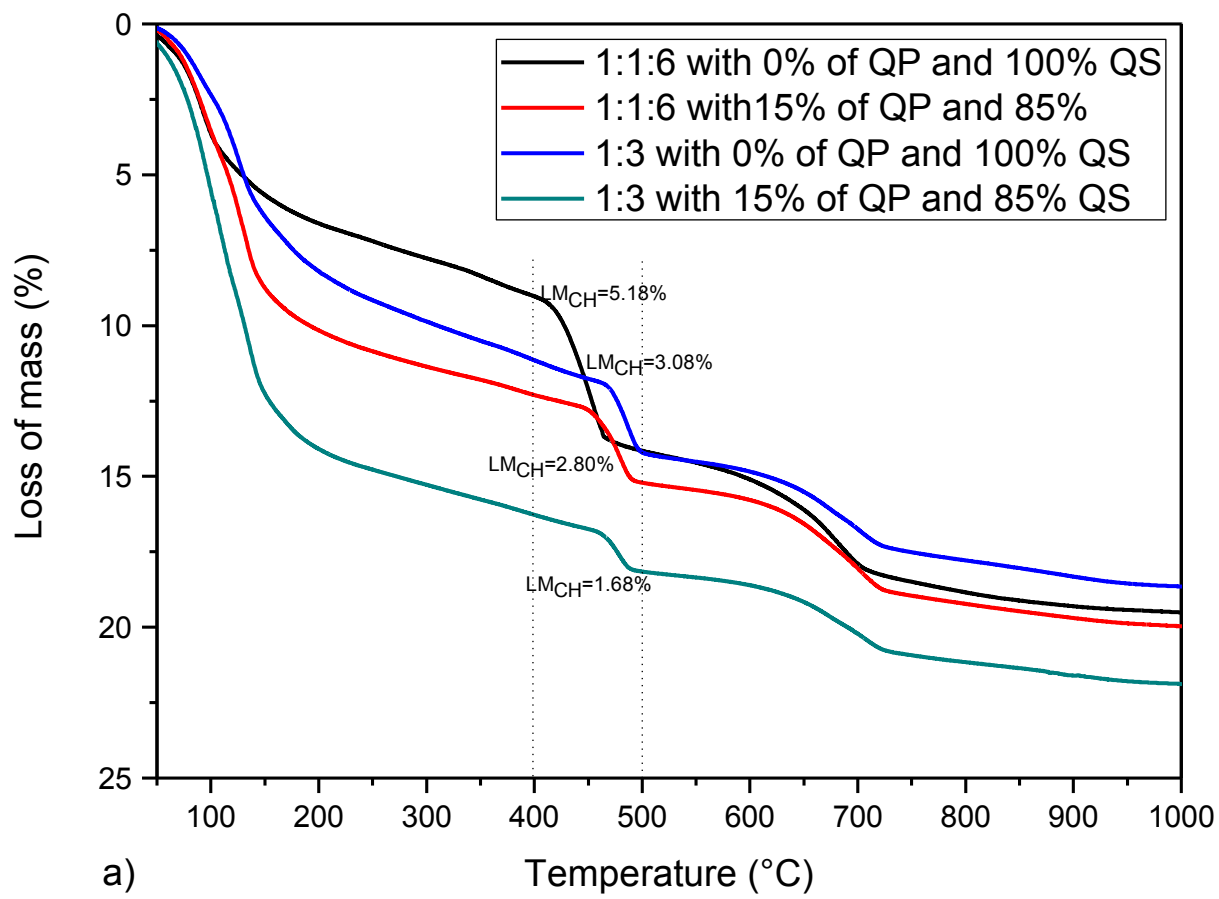




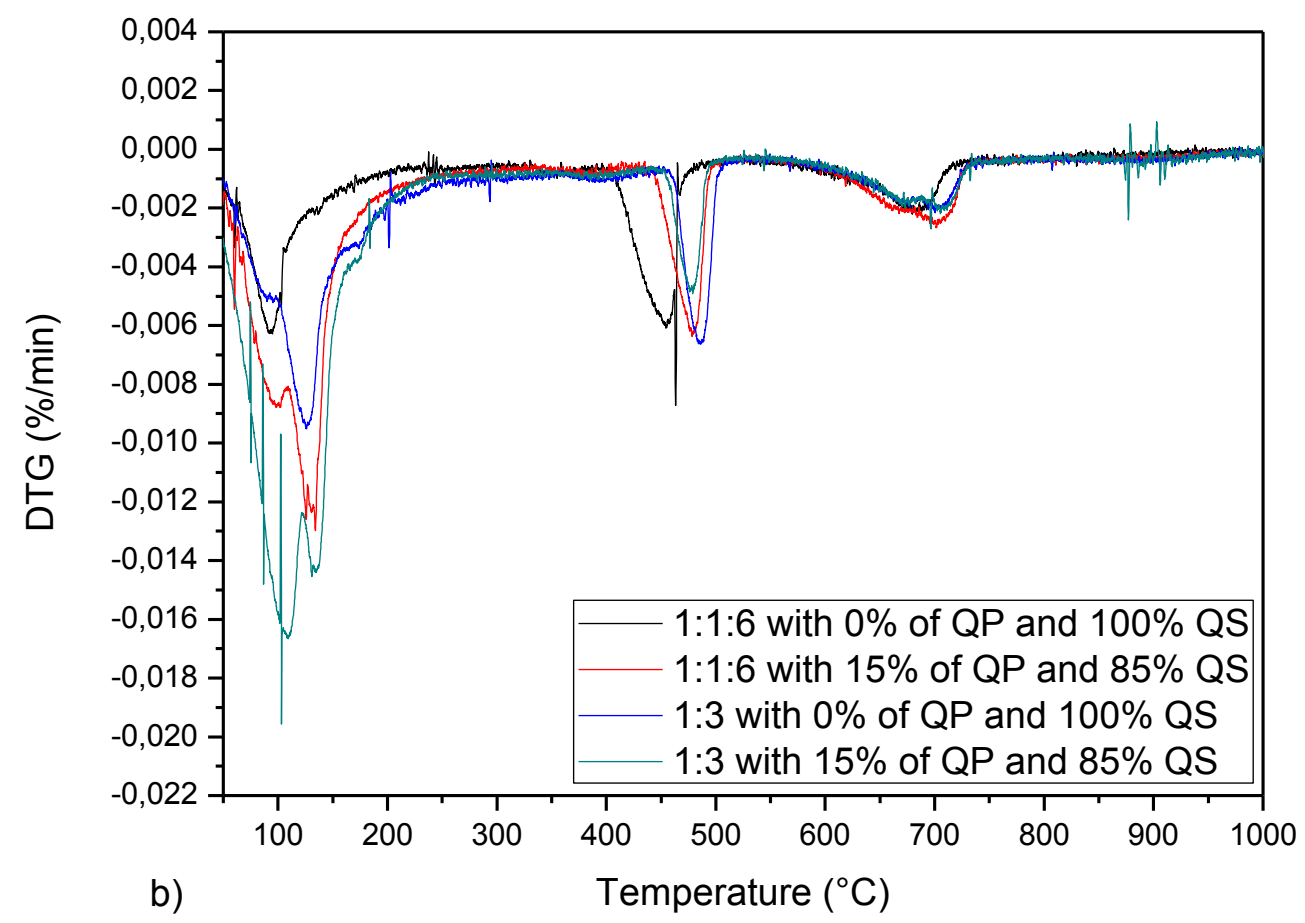

Figure 3: TG and DTG curves of the mortar samples under study after immersion in sodium sulfate solution (a) TG and (b) DTG

The curves presented in Figure 3 show similar behavior for all mortar samples blended with quartzite residues. They presented endothermic peaks distributed in three well-defined zones according to the temperature ranges. The first zone comprised the range from 25 to $200{ }^{\circ} \mathrm{C}$, in which occurred loss of mass due to the elimination of free water and partial dehydration of the C-S-H. The second zone comprised the range from 200 to $500{ }^{\circ} \mathrm{C}$, in which occurred loss of mass due to the hydroxyls $\left(\mathrm{OH}^{-}\right)$, which in turn proved the presence of portlandite (calcium hydroxide) in the samples under study, as well as its consumption, responsible for the formation of primary ettringite. The third zone comprised the range from 500 to $800{ }^{\circ} \mathrm{C}$, in which occurred the loss of $\mathrm{CO}_{2}$, proving that there was formation of the calcite (calcium carbonate). These results are similar to those found by Balasubramanian et al. [25] in their studies on ornamental rock residues applied to mortar.

The loss of mass (LM) due to the portlandite consumption for ettringite formation in the range of 400 and $500{ }^{\circ} \mathrm{C}$ was more noticeable in the mixtures that do not present QP in their compositions (Figure 3a). This happened because the QP makes the samples denser, acting as a filler material, improving the system packing, reducing the porosity of the mortar samples, and consequently attenuating the formation of the ettringite.

\section{CONCLUSION}

After the studies on the durability of mortar samples blended with QS and QP residues under sulfate attack, can conclude that: the aggregates formed by quartzite residues had expansions capable of compromising the durability of the mortar prepared with Portland cement without addition of pozzolane, and therefore they cannot be considered innocuous to the sulfate attack. The presence of alumina in the residues and in the cement was not capable of forming enough ettringite to start the mechanical deterioration of the test specimens subjected to the sulfate attack. The X-ray diffractograms revealed that the samples without addition of QP showed a higher reflection formation characteristic of the ettringite. The thermogravimetric curves showed that the presence of QP mitigated the loss of mass related to the consumption of portlandite for formation of ettringite in the range of 400 and $500^{\circ} \mathrm{C}$. 


\section{BIBLIOGRAPHY}

[1] BARROS, S.V.A., MARCIANO, J.E.A., FERREIRA, H.C., et al., "Addition of quartzite residues on mortars: Analysis of the alkali aggregate reaction and the mechanical behavior", Construction and Building Materials, v.118, n.15, pp.344-351, 2016.

[2] GESEOGLU, M., GUNEYISI, E., KOCABAG, M.E., et al., "Fresh and hardened characteristics of selfcompacting concretes made with combined use of marble powder, limestone filler, and fly ash", Construction and Building Materials, v.37, p.160-170, 2012.

[3] ULEBEYLI, G.C., BILIR, T., ARTIR, R., "Durability Properties of Concrete Produced by Marble Waste as Aggregate or Mineral Additives”, Procedia Engineering, v.161, pp.543 - 548, 2016.

[4] MAURI, J., DIAS, D.P., CORDEIRO, G.C. DIAS, A.A., “Argamassa geopolimérica: estudo da degradação por sulfato de sódio e ácido sulfúrico”, Matéria, v.14, n.3, p. 1039 - 1046, 2009.

[5] ANDRÉ, A., BRITO, J., ROSA, A., PEDRO, D., "Durability performance of concrete incorporating coarse aggregates from marble industry waste", Journal of Cleaner Production, v.65, n.15, p.389-396, 2015.

[6] BACARJI, E., TOLEDO FILHO, R.D., KOENDERS, E.A.B., et al., "Sustainability perspective of marble and granite residues as concrete fillers", Construction and Building Materials, v.45, pp.1-10, 2013.

[7] GAMEIRO, F., BRITO, J., SILVA, D.C., "Durability performance of structural concrete containing fine aggregates from waste generated by marble quarrying industry”, Engineering Structures, v.59, p.654 -662, 2014.

[8] ERCIKDI, B., KULEKCI, G., YILMAZ, T., "Utilization of granulated marble wastes and waste bricks as mineral admixture in cemented paste backfill of sulphide-rich tailings", Construction and Building Materials, v.93, n.15, p.573-583, 2015.

[9] TENNICH, M., KALLEL, A., OUEZDOU, M.B., "Incorporation of fillers from marble and tile wastes in the composition of self-compacting concretes”, Construction and Building Materials, v.91, n.30, pp.65-67, 2015.

[10] MERIDA, A., KHARCHI, F., "Pozzolan Concrete Durability on Sulphate Attack", Procedia Engineering, v.114, pp.832 - 837, 2015.

[11] AL-AMOUDI, O. S. B., MASLEHUDDIN, M., SAADI, M. M., "Effect of magnesium sulfate and sodium sulfate on the durability performance of plain and blended cements", ACI Materials Journal, v.92, n.1, p.15-24, 1995.

[12] CORINALDESI, V., MORICONI, G., NAIK, T. R., "Characterization of marble powder for its use in mortar and concrete", Construction and Building Materials, v.24, n.1, p.113-117, 2010.

[13] WERITZ, F., TAFFE, A., SCHAURICH, D., WILSCH, G., "Detailed depth profiles of sulphate ingress into concrete measured with laser-induced break down spectroscopy", Construction and Building Materials, v.23, n.1, pp. $275-283,2009$.

[14] VAN AARDT, J. H. P., VISSER, S., "Influence of alkali on the sulphate resistance of ordinary portland cement mortar", Cement and Concrete Research, v.15, n.3, p.485-494, 1985.

[15] MEHTA, P.K., MONTEIRO, P.J.M., Concrete: Microstructure, properties, and materials, McGrawHill Professional, São Paulo, Brazil, 4th Edition. 675p. 2013.

[16] CAPRARO, A.P.B., MEDEIROS, M.H.F., HOPPE FILHO, J., et al., "Internal Sulphate Reaction (ISR) as degradation of the cement matrix: behavior of pastes dosed with different amounts of contamination by sulfate", Revista ALCONPAT, v.7, n.2, pp.119-134, 2017.

[17] ASSOCIAÇÃO BRASILEIRA DE NORMAS TÉCNICAS. NBR 13583: Portland Cement - Determination of volumetric change of Portland cement mortar bars exposed to sodium sulphate solution. Rio de Janeiro: ABNT, 2014.

[18] ASSOCIAÇÃO BRASILEIRA DE NORMAS TÉCNICAS. NBR 16697: Portland Cement - Requirements. Rio de Janeiro: ABNT, 2018.

[19] ASSOCIAÇÃO BRASILEIRA DE NORMAS TÉCNICAS. NBR 7211: Aggregates for concrete - Specification. Rio de Janeiro: ABNT, 2009.

[20] ASSOCIAÇÃO BRASILEIRA DE NORMAS TÉCNICAS. NBR 13276: Mortars applied on walls and ceilings - Determination of the consistence index. Rio de Janeiro: ABNT, 2002. 
[21] AMERICAN SOCIETY FOR TESTING AND MATERIALS. ASTM C 780 standard Test Method for Preconstruction and Construction Evaluation of Mortars for Plain and Reinforced Unit Masonry. ASTM, 2006.

[22] AMERICAN SOCIETY FOR TESTING AND MATERIALS. ASTM C 452 Standard Test Method for Potential Expansion of Portland-Cement Mortars Exposed to Sulfate. ASTM, 2002.

[23] ASSOCIAÇÃO BRASILEIRA DE NORMAS TÉCNICAS. NBR 13281: Mortars applied on walls and ceilings - Requirements. Rio de Janeiro: ABNT, 2005.

[24] BROWN, P. W., "An evaluation of the sulfate resistance of cements in a controlled environment”, $C e$ ment and Concrete Research, v.11, n.5-6, pp.719-727, 1981.

[25] BALASUBRAMANIAN, J., GOPAL, E., PERIAKARUPPAN, P., "Strength and microstructure of mortar with sand substitutes", Građevinar, v.68, n.1, pp.29-37, 2016.

\section{ORCID}

Sâmea Valensca Alves Barros Gelmires de Araújo Neves Romualdo Rodrigues Menezes Gerbeson Carlos Batista Dantas Patrícia Mendonça Pimentel
https://orcid.org/0000-0002-9035-486X

https://orcid.org/0000-0002-2900-1600

https://orcid.org/0000-0003-4316-2168

https://orcid.org/0000-0002-6662-5789

https://orcid.org/0000-0002-3080-0688 